\title{
Genome-Wide Association Study for Resistance to the Meloidogyne javanica Causing Root-Knot Nematode in Soybean
}

\author{
Jean Carlos Alekcevetch ${ }^{1}$, André Luiz de Lima Passianotto ${ }^{2}$, Everton Geraldo Capote Ferreira ${ }^{1}$, \\ Adriana Brombini dos Santoss ${ }^{3}$, Danielle Cristina Gregório da Silva ${ }^{3}$, Waldir Pereira Dias ${ }^{3}$, \\ François Belzile ${ }^{4}$, Ricardo Vilela Abdelnoor ${ }^{3}$, Francismar Correa Marcelino-Guimarães ${ }^{3^{*}}$ \\ ${ }^{1}$ Londrina State University (UEL), Celso Garcia Cid Road, km 380, Londrina, PR, Brazil \\ ${ }^{2}$ Department of Plant Agriculture, University of Guelph, Guelph, Ontario, N1G 2V7, Canada \\ ${ }^{3}$ Brazilian Agricultural Research Corporation - National Soybean Research Center (Embrapa Soja), Carlos João \\ Strass road, Warta County, PR, Brazil \\ ${ }^{4}$ Department of Plant Sciences and Institute of Integrative Biology and Systems (IBIS), Université Laval, Quebec \\ City, Quebec, G1V 0A6, Canada \\ *Correspondence: francismar.marcelino@embrapa.br
}

\begin{abstract}
Meloidogyne javanica causing root-knot nematode in soybean is an important problem in soybean areas, leading to several yield losses. Some accessions have been identified carrying resistance loci to this nematode specie. In this study, a set of 317 soybean accessions were characterized for resistance to M. javanica. Genome-wide association study (GWAS) was performed using SNPs from genotyping-by-sequencing (GBS), and a region of $29.2 \mathrm{Kbp}$ on chromosome 13 was identified. The haplotype analysis showed that SNPs were able to discriminate susceptible and resistant accessions, leading to 25 accessions sharing the resistance locus. Furthermore, 5 accessions may be new M. javanica resistance sources. The screening of the SNPs in the USDA soybean germplasm showed that several accessions previous reported as resistance to other nematodes also showed the resistance haplotype on chromosome 13. High levels of concordance among the phenotypes of Brazilian cultivars and the SNPs in chromosome 13 were observed. A in silico analysis of the mapped region on soybean genome revealed a presence of 5 genes with structural similarity with major resistance genes. The expression levels of the candidate genes in the interval demonstrated a potential pseudogene, and other two model genes up-regulated in the resistance source after pathogen infection. The SNPs associated to the region conferring resistance is an important tool for introgression of the resistance by marker-assisted selection in soybean breeding programs.
\end{abstract}

Keywords: Mixed linear model; Genotyping-by-Sequencing; Functional validation; RT-qPCR; resistance genes; GWAS

\section{Introduction}

Soybean [Glycine max (L.) Merrill] is one of the most important oil and protein crops in the world. Currently, Brazil is the largest producer with 127.60 million metric tons followed by United States with 110.18 million tons [1]. Despite the success of the soybean crop both in the United States and Brazil, the crop is frequently challenged by biotic stresses. In soybean, among all phytosanitary problems, nematode parasitism deserves special attention. It is estimated that nematodes can cause annual losses of $10 \%$ to $15 \%$, representing almost U $\$ 78$ billion worldwide [2]. The Meloidogyne genus is composed of more than 90 species, but basically M. javanica and M. incognita are the main members of this genus with the largest economic importance in the worldwide soybean production $[2,3]$. In Brazil, losses due to these two nematode species have been reported in all the main regions where 
soybean is cultivated, including Rio Grande do Sul, Paraná, Mato Grosso, Mato Grosso do Sul [4,5]. The use of resistant cultivars and crop rotation are the best ways to decrease and control nematode populations, thus minimizing production losses and allowing cultivation in infected areas [6].

Studies have been conducted in order to identify resistance sources in soybean accessions. For example, through the phenotypic screening of 2,370 soybean genotypes it was possible to identify the PI 230977 as source of resistance to M. javanica, as well as the PI 200538 as source of resistance to Meloidogyne arenaria [7]. In another study, soybean breeding lines and reported resistance sources were evaluated to different nematode species. As results, it was observed that PI 595099 and PI 230977 showed resistance reaction to both M. javanica and M. arenaria, and for some races of H. glycines [8]. Inheritance of $M$. javanica was identified as quantitative and showing high heritability in PI 595099 and cv. CD 201 [4]. Currently, in the Brazilian market, more than 80 cultivars resistant or moderately resistant to nematodes are available, however, there are few varieties with strong resistance to $M$. javanica. The resistance present in Brazilian soybean varieties is derived from only one source, the North American cultivar Bragg, in which resistance is reported to be quantitative [4,9].

Genetic mapping studies have been performed to identify loci in soybean genome bearing $M$. javanica resistance. Initially, a $\mathrm{F}_{2}$ progeny derived from the cross between the cv. CNS and PI 230977 was used with RFLP markers to identified markers linked to the resistance. It was identified two QTLs conditioning resistance in two different regions. A QTL located on chromosome 13 accounted for $46 \%$ of the variation in galls number, and another one in chromosome 01 , accounted for $13 \%$ [10]. Interestingly, the resistance of a $\mathrm{F}_{2}$ progeny, derived from a cross between PI 200538 (resistant to $M$. arenaria) and the susceptible cv. CNS, was mapped using RFLP markers in the same region in the chromosome 13 (QTL explained 32\% of the variation in gall number) [11]. In another work, a population of $60 \mathrm{~F}_{2}$ progeny derived from the cross between cv. Gazelle (resistant to M. javanica) and cv. Prima (susceptible) was used for mapping resistance to M. javanica in the Chromosome 13 as well. Finally, populations derived from crosses between CD 201 and BRS 133, and between PI 595099 and BRS 133, were used to identified SSR markers linked to resistance to M. javanica, as results, markers located on chromosome 13 were identified $[12,13]$.

All these previous studies were carried out using RFLP, AFLP and SSR markers and bi-parental populations, which access only the allelic diversity segregating between the two parents and explore limited number of recombination events [14]. Nowadays, different high throughput genotyping methodologies, for example, Genotyping-by-Sequencing (GBS) [15], SoySNP50K chip [16] and whole-genome resequencing [17], have been used to obtain SNPs for Genome-Wide-Association Studies (GWAS). This approach has been receiving unprecedented attention once it overcomes several limitations of QTL mapping and easily expand the knowledge about the occurrence of new sources of resistance. It contains high resolution, cost efficiency, and it is non-requirement of pedigrees or crosses.

GWAS have been performed for discovery of the genomics regions underlying important diseases in soybean. For example, genomic regions for Sclerotinia stem rot resistance (white mold) $[18,19]$, brown stem rot (BSR) [20], Southern root-knot nematode [21], soybean cyst nematode [22] and soybean stem canker [23] were identified by GWAS. The further functional characterization of candidate genes in these regions have been conducted applying different methodologies, as RNAseq, RT-qPCR and transgenic approaches, in order to better understand the molecular mechanisms involved in plant resistance. Fuganti [24], studying the resistance to M. javanica in soybean, observed that polymorphism previous associated to resistance was located inside the promoter of the Gmhsp17.6-L gene. The comparison of the nucleotide sequences showed differences in number of AT insertions between the resistant (PI 595099) and susceptible (BRS 133) progenitors and $\mathrm{F}_{2}$ individuals, which were hypothesized to be involved in the regulation of the expression levels of Gmhsp17.6-L. It was observed that the resistant individuals showed higher expression levels of the Gmhsp17.6-L when compared with the susceptible individuals. Transcriptome studies have been also conducted in PI 595099 in order to identify candidate genes involved in interaction between M. javanica and soybean. All the resulting data suggested the key role of glycosyltransferases, auxins and components of 
gibberellin signal transduction, biosynthesis and deactivation pathways in the resistance reaction $[25,26]$.

The objective of this study was to identify SNPs associated with M. javanica resistance using a diverse set of 317 soybean accessions by GWAS approach. In order to further comprehend the role of the genomic regions identified by GWAS, resistance gene candidates present in the LD block were selected for studying of their expression levels by RT-qPCR after pathogen infection, using a susceptible and resistant accessions.

\section{Results}

\subsection{M. javanica evaluation in the soybean accessions}

Among the 317 soybean accessions comprising the association panel (Supplementary Table S1), 30 accessions received scores between 1.0 and 2.5 (indicating a high level of resistance), 82 accessions received scores ranging from 2.6 to 3.5, while the remaining 205 accessions exhibited scores higher than 3.6 (classifying as susceptible materials). (Figure 1). Considering the population size and the number of the accessions in each phenotypic class, it was assumed that the genomic regions that are responsible for resistance and susceptibility were well sampled. The M. javanica resistance sources PI 595099, cv. Bragg and PI 437127 B showed the lowest score (1.0), whereas the PI 230977 showed the score of 2.5, being classified as resistant. Interestingly, another previously described resistance source, PI 200538, showed the score of 2.7, thus, classified as moderately resistant. In the susceptible group, the cv. BRS 133, showed a score of 4.5 (susceptible), which previously was classified as susceptible to M. javanica,.

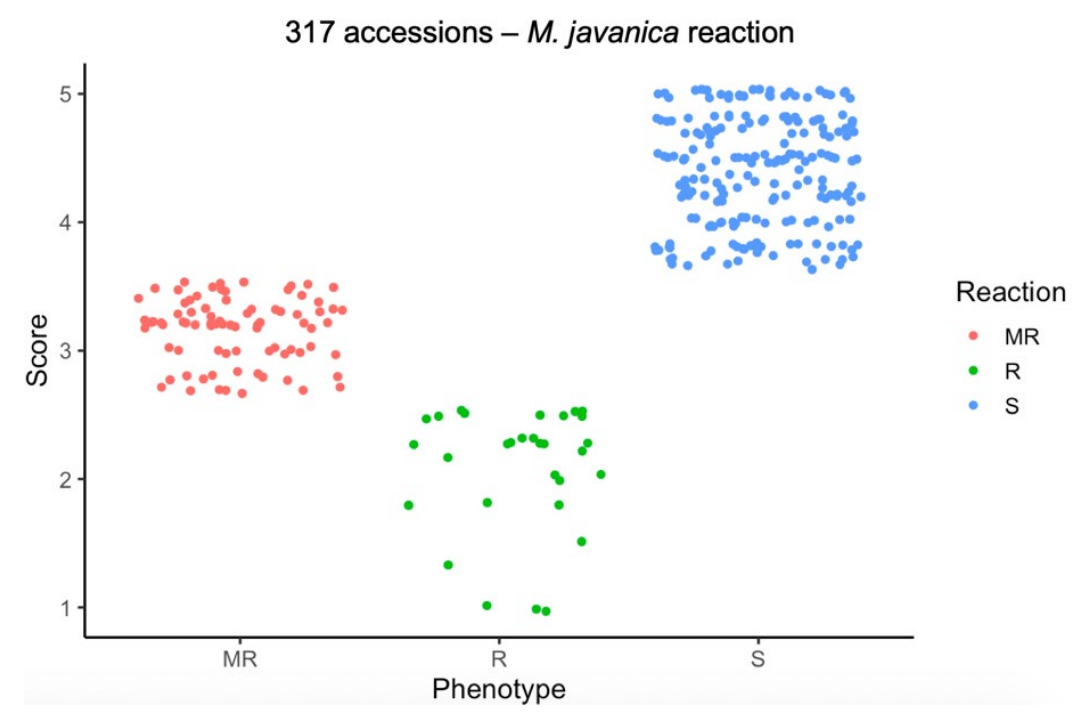

Figure 1. Graphic distribution of resistant (R), moderately resistant (MR) and susceptible (S) soybean genotypes against the M. javanica pathogen.

It can be observed that only approximately $10 \%$ of the accessions were resistant to $M$. javanica, but just three accessions (1\%) showed the lower score of 1.0 . Around $26 \%$ were classified as moderately resistant. Indeed, approximately $65 \%$ of the panel was classified as susceptible to $M$. javanica.

\subsection{Genome-Wide Association Study for M. javanica Resistance}


A total of 44,992 SNPs was identified by GBS along the 20 soybean chromosomes, providing an extensive coverage of the genome. This represented an average of 2,250 SNPs per chromosome or one variation every $21 \mathrm{~kb}$ approximately. The largest number of variants (8.5\% of total SNPs) was found, as expected, on the largest chromosome (Chr18, 58Mb). On the other hand, the smallest number of variants was not found on the smallest chromosome (Chr11 - 34Mb; 1,382 variants), but rather on Chr 12 (40 Mb) (only 1,255 variants) (Supplementary Table S2). Regarding the marker distribution within coding vs non-coding regions, SNPs were identified in all genes segments as well as in the intergenic regions, with the intergenic regions presenting the largest number of SNPs, followed by downstream regions, intronic region, upstream region, exons, 3’UTR and 5`UTR (Supplementary Table S2).

A Principal Component Analysis (PCA) was performed in order to capture the population structure in the panel. The PC1 explained approximately $9 \%$ of the observed genetic variance, PC2 approximately $5 \%$ and PC3 approximately $4 \%$, together, the first three PCs explained about $18 \%$ of the total genetic variance (Figure 2a). The GWAS was conducted using a cMLM taking into account both genetic relatedness (VanRanden matrix) and population structure (it was used the first three PC's). The quantile-quantile plot showed that observed p-values strongly deviated from the expected p-values in few SNPs (Figura 2b), which means that the cMLM model was appropriated for GWAS.

A.

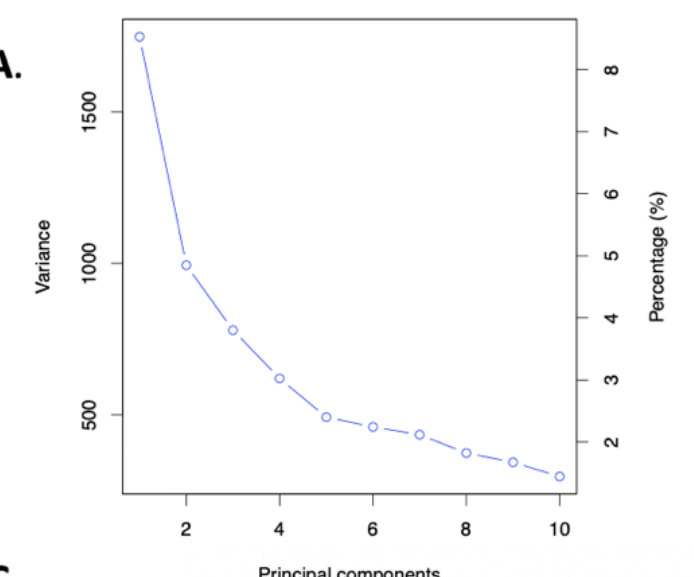

C.

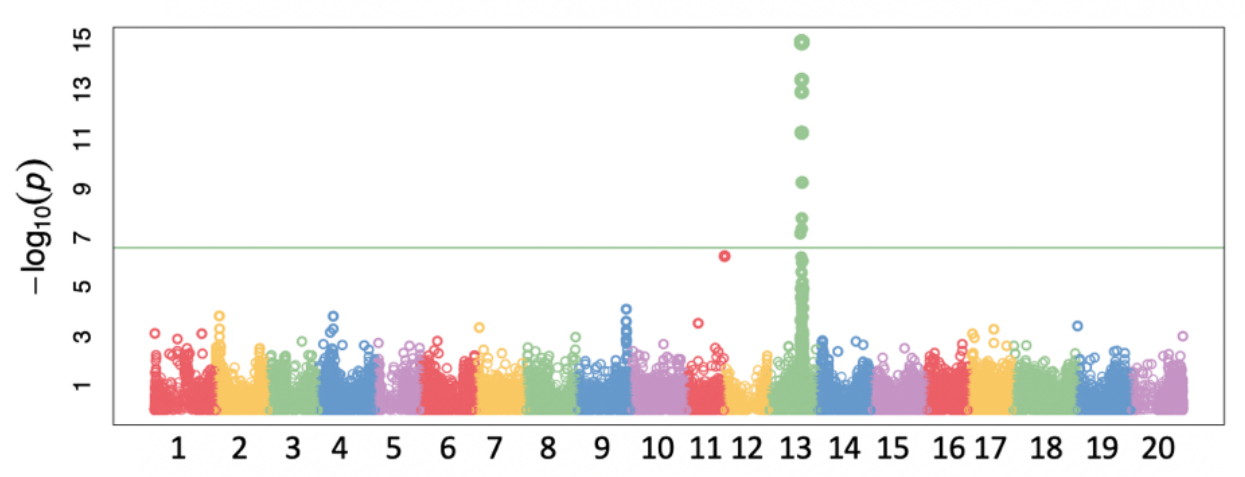

Figure 2. Genetic structure of accession panels according the first ten principal components (a), Quantile-Quantile Plot (QQplot) of p-values (b), Manhattan plot of GWAS, demonstrating the SNPs distribution along all 20 soybean chromosomes. Significant associations are represented above threshold line (c)

10 SNPs, all located in the same region of chromosome 13 (Figure 2c), were identified as significantly associated (FDR adjusted $p$-value $=1,23 \mathrm{E}^{-15}$ to $1,69 \mathrm{E}^{-08}$ ) with resistance to $M$. javanica plot (Table 1). The strongest degree of association (FDR $\left.=1,00 \mathrm{E}^{-11}\right)$ was shared by five SNPs. We chose to name these SNPs as GBSRmj (SNPs from GBS approach related to resistance to M. javanica - Rmj). The five 5 peak SNPs explained approximately $34 \%$ of the phenotypic variation, and the remaining 
SNPs ranging from $29 \%$ to $24 \%$. The physical interval delimited by the SNPs was only $29.2 \mathrm{kbp}$, ranging between position $30,776,090$ to $30,805,508$ in the chromosome 13 , and all of the those are located in intergenic regions.

Table 1. SNPs significantly associated with resistance to M. javanica identified by GWAS

\begin{tabular}{|c|c|c|c|c|c|c|}
\hline SNP ID & $\mathrm{Chr}^{\mathrm{a}}$ & Pos $(b p){ }^{b}$ & p.value & MAF c & $\mathbf{r}^{2 \mathrm{~d}}$ & FDR Adjusted p-values \\
\hline GBSRmj961 & 13 & 30804961 & $1,23 \mathrm{E}-15$ & 0,31 & 0,34 & $1,00 \mathrm{E}-11$ \\
\hline GBSRmj499 & 13 & 30805499 & $1,23 \mathrm{E}-15$ & 0,31 & 0,34 & $1,00 \mathrm{E}-11$ \\
\hline GBSRmj500 & 13 & 30805500 & $1,23 \mathrm{E}-15$ & 0,31 & 0,34 & $1,00 \mathrm{E}-11$ \\
\hline GBSRmj508 & 13 & 30805508 & $1,23 \mathrm{E}-15$ & 0,31 & 0,34 & $1,00 \mathrm{E}-11$ \\
\hline GBSRmj090 & 13 & 30776090 & 1,33E-15 & 0,29 & 0,34 & 1,00E-11 \\
\hline GBSRmj409 & 13 & 30792409 & $4,20 \mathrm{E}-14$ & 0,31 & 0,32 & 2,64E-10 \\
\hline GBSRmj474 & 13 & 30792474 & $1,30 \mathrm{E}-13$ & 0,31 & 0,31 & $7,03 \mathrm{E}-10$ \\
\hline GBSRmj686 & 13 & 30804686 & $5,76 \mathrm{E}-12$ & 0,27 & 0,29 & $2,18 \mathrm{E}-08$ \\
\hline GBSRmj726 & 13 & 30804726 & $5,76 \mathrm{E}-12$ & 0,27 & 0,29 & 2,18E-08 \\
\hline GBSRmj752 & 13 & 30804752 & $5,76 \mathrm{E}-12$ & 0,27 & 0,29 & $2,18 \mathrm{E}-08$ \\
\hline
\end{tabular}

a Chromosome, ${ }^{b}$ Physical position of the SNPs in the soybean genome (W82.a2.v1), ${ }^{c}$ Minor allele frquency, ${ }^{\mathrm{d}} \mathrm{R}$ squared value of the model with the SNP.

According to the LD analysis, almost all the SNPs were in a unique LD block (the only exception was the GBSRmj090). This LD block comprised a reduced region of $13.1 \mathrm{~Kb}$, which is flanked by SNPRmj409 and SNPRmj508. (Figure 3a). This LD block contains only one gene model (Glyma.13g194700), which coding a protein with the LRR domain. Interestingly, the SNPs are located in a region harboring genes containing LRR domain, which is often related to resistance genes in plants (Figure $3 b$ ).

A.

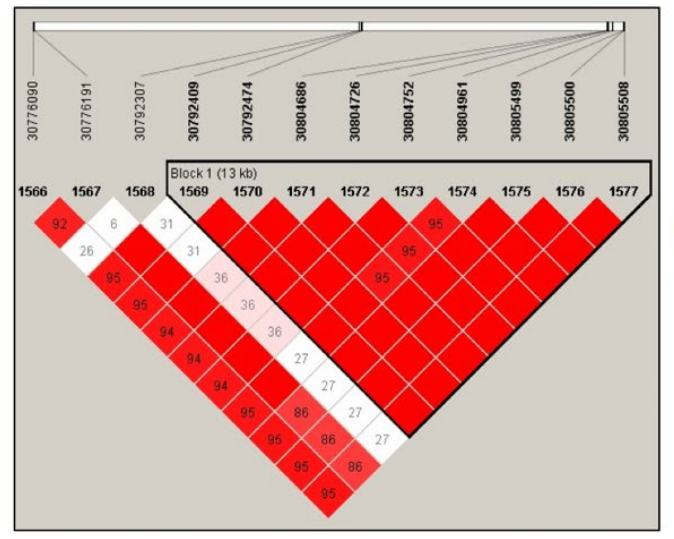

B.

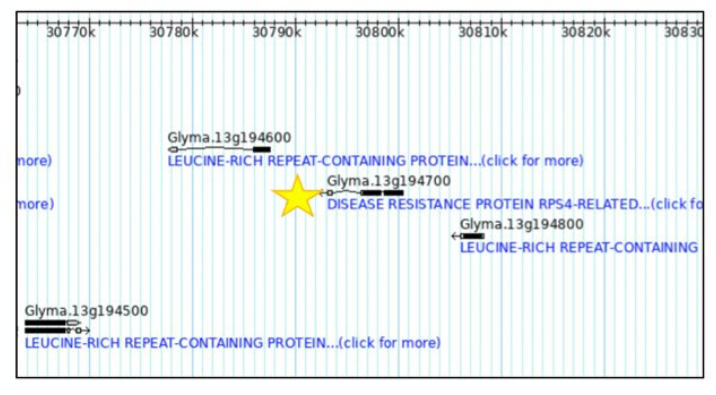

Figure 3. Genomic distribution of mapped SNPs. LD block (delimited by black lines) containing all the nine associated SNPs, and one SNP located outside of LD block. (a), genes located in the region identified by the SNPs from GWAS, (yellow star represents Glyma.13g194700, which is located inside of the LD block (b).

Based on the results obtained in the linkage disequilibrium analysis, that was performed considering full population and $44.992 \mathrm{SNPs}$, the regression curve fitted to the LD plot falls below $\mathrm{r}^{2}$ 
$=0.2$ at $\sim 0,15 \mathrm{Mb}$ (Supplementary Table S3). A similar $\mathrm{r}^{2}$ value was obtained when exclusively chromosome 13 was analyzed (Supplementary Table S3).

Based on the SNPs identified by GWAS, using either the peak SNP, GBSRmj961 $(30,804,961)$, or the haplotype composed by the four peak SNPs (SNPs are redundant between them), it was obtained the same results in the haplotype analysis (Supplementary Table S4). That is, it was possible to appropriately separate the resistant and moderately resistant accessions from susceptible accessions. At the peak SNP, the $C$ allele was present in 25 from the 30 resistant accessions (including the PI 595099, PI 230977, cv. Bragg, cv. CD 201 and PI 200538), and in approximately 66\% of the moderately resistant accessions and only in $10 \%$ of susceptible accessions. In contrast, the alternative allele (T) was present in 5 from the 30 resistant accessions, and in approximately $34 \%$ of the moderately resistant accessions and 184 of the 205 accessions of the susceptible set (Table 2).

Later we used the USDA soybean germplasm collection, composed by 20,087 and Glycine max and Glycine soja, to search by the peak SNP identified here. After the removing of heterozygous genotypes, it was obtained a total of 19,978 accessions. In the genomic data, it was possible to identified two SNPs, the SNPs Chr13:30,804,961 (the peak SNP from our GWAS) and the Chr13:30,805,508 (which one, is redundant with the peak SNP). Selecting $C$ in the position Chr13:30,804,961 (resistant alleles), 2,150 accessions were selected, otherwise, while selecting the T, 17,828 accessions were selected, revealing that approximately $11 \%$ of the whole USDA collection may posse the M. javanica resistance QTL on the chromosome 13 (Supplementary Table S4).

Table 2. Haplotype obtained using the peak SNPs from GWAS

\begin{tabular}{|c|c|c|c|c|c|c|c|}
\hline \multirow[b]{2}{*}{ Haplotype ID } & \multicolumn{4}{|c|}{ Position in the Soybean Genome - Chromosome 13} & \multicolumn{3}{|c|}{ M. javanica reaction ${ }^{b}$} \\
\hline & $30.804 .961^{\mathrm{a}}$ & 30.805 .499 & 30.805 .500 & 30.805 .508 & $\mathbf{R}$ & MR & S \\
\hline Hap-Resistant & $\mathrm{C}$ & $\mathrm{C}$ & A & $\mathrm{T}$ & 25 & 54 & 21 \\
\hline Hap-Susceptible & $\mathrm{T}$ & A & G & G & 5 & 28 & 184 \\
\hline Total $=317$ & & & & & 30 & 82 & 205 \\
\hline
\end{tabular}

In order to develop and test a genotyping assay using the peak SNPs identified in our GWAS, it was selected a set of commercial Brazilian cultivars, which almost all of them have information in the literature about resistance to M. javanica (Supplementary Table S5). In the set of resistant cultivars to M. javanica, all of them shared the haplotype 30,804,961 (C) and 30,805,508 (T). In the moderately resistant, 13 shared the resistant haplotype, while five cultivars were described as moderately resistant, but shared the susceptible SNP (Figure 4a). In the susceptible set composed by 38 cultivars, 35 shared the susceptible haplotype, and just three cultivars described as susceptible in the literature, showed the resistant haplotype (Figure $4 \mathrm{~b}$ ). Therefore, these results at least demonstrate a high degree of concordance among these SNPs markers and the M. javanica resistance/susceptibility in the set of Brazilian cultivars evaluated. 
A.

\begin{tabular}{|c|c|c|c|}
\hline Plant name & Chr13:30804961 & Chr13:30805508 & $\begin{array}{c}\text { Phenotype M } \\
\text { javanica }\end{array}$ \\
\hline BRS 284 & $\mathrm{C}$ & T & $\mathrm{R}$ \\
\hline BRS Valiosa RR & C & $\mathrm{T}$ & $\mathrm{R}$ \\
\hline BRSMG 850 G RR & C & $\mathrm{T}$ & $\mathrm{R}$ \\
\hline CD 201 & $\mathrm{C}$ & $\mathrm{T}$ & $\mathrm{R}$ \\
\hline $\mathrm{BRS} / \mathrm{GO} 8360$ & $\mathrm{c}$ & $\mathrm{T}$ & $\mathrm{R}$ \\
\hline BRS 239 & $\mathrm{C}$ & $\mathrm{T}$ & $\mathrm{R}$ \\
\hline BRS $7380 \mathrm{RR}$ & $\mathrm{C}$ & $\mathrm{T}$ & $\mathrm{R}$ \\
\hline BRS 7980 & $\mathrm{C}$ & $\mathrm{T}$ & $\mathrm{R}$ \\
\hline CD 219 RR & $\mathrm{C}$ & $\mathrm{T}$ & $\mathrm{R}$ \\
\hline FT Cometa & $\mathrm{c}$ & $\mathrm{T}$ & $\mathrm{R}$ \\
\hline NA 7337 RR & C & $\mathrm{T}$ & $\mathrm{R}$ \\
\hline Conquista & $\mathrm{C}$ & $\mathrm{T}$ & MR \\
\hline Santa Rosa & $\mathrm{C}$ & $\mathrm{T}$ & MR \\
\hline BMX Turbo RR & C & $\mathrm{T}$ & MR \\
\hline BRSGO Mineiros RR & $\mathrm{C}$ & $\mathrm{T}$ & MR \\
\hline BRSMG $752 \mathrm{~S}$ & $\mathrm{C}$ & $\mathrm{T}$ & MR \\
\hline BRS 283 & C & $\mathrm{T}$ & MR \\
\hline BRS 313 & $\mathrm{C}$ & $\mathrm{T}$ & MR \\
\hline BRS $8160 \mathrm{RR}$ & $\mathrm{C}$ & $\mathrm{T}$ & MR \\
\hline BRS Juliana RR & C & $\mathrm{T}$ & MR \\
\hline BRS Macota & C & $\mathrm{T}$ & MR \\
\hline Emgopa 313 & $\mathrm{C}$ & $\mathrm{T}$ & MR \\
\hline MSoy 8001 & $\mathrm{C}$ & $\mathrm{T}$ & MR \\
\hline TMG 103 RR & $\mathrm{C}$ & $\mathrm{T}$ & MR \\
\hline VMAX RR & $\mathrm{T}$ & G & MR \\
\hline BRS/GO Chapadões & $\mathrm{T}$ & G & MR \\
\hline BRSMG 810C & $\mathrm{T}$ & G & MR \\
\hline CD 206 & $\mathrm{~T}$ & G & MR \\
\hline Embrapa 4 & $T$ & G & MR \\
\hline
\end{tabular}

B.

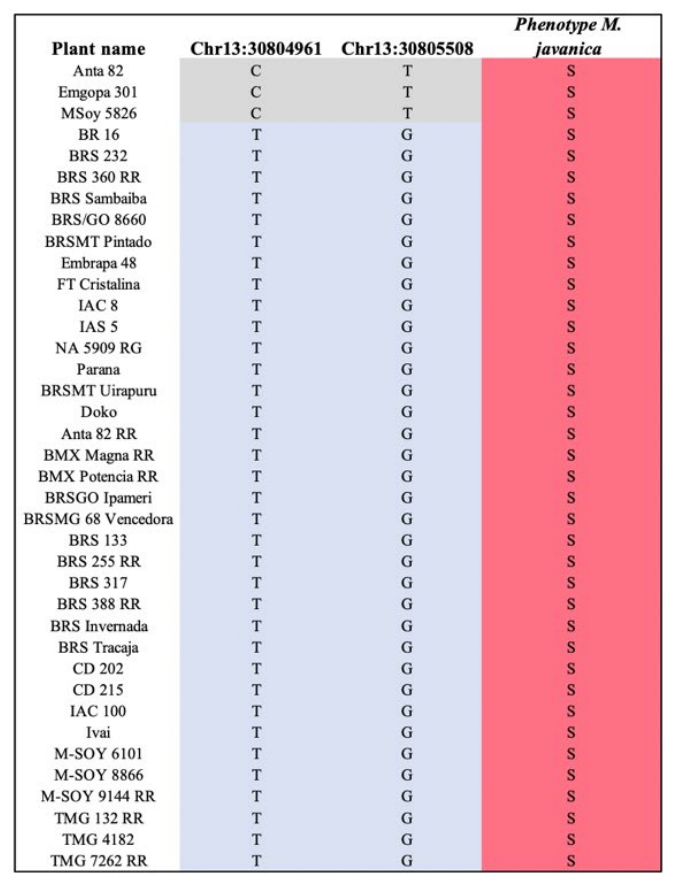

Figure 4. Concordance among the haplotypes and the resistance profile for M. javanica in Brazilian cultivars, which $\mathrm{R}$ is resistant, MR is moderately resistant and $\mathrm{S}$ is susceptible to this nematode.

\subsection{Expression levels of candidate genes for resistance in the region identified by GWAS}

The expression profile of five genes located near mapped SNPs were evaluated by RT-qPCR (Supplementary Table S6). In general, the resistant genotype (PI 595099) showed an expression level increased on 2DPI, four days earlier than BRS 133 (susceptible genotype) for Glyma.13g194600, Glyma.13g194800, Glyma.13g194900. The expression profile changed in 6 PDI, when gene expression in PI 595099 turned down and increased in BRS 133, creating a new general top level of expression. The gene Glyma.13g194700 was the unique that showed a different expression pattern, maintaining a constantly increasing to both genotypes, with higher levels of expression in the susceptible line compared with the resistant source (Figure 6).

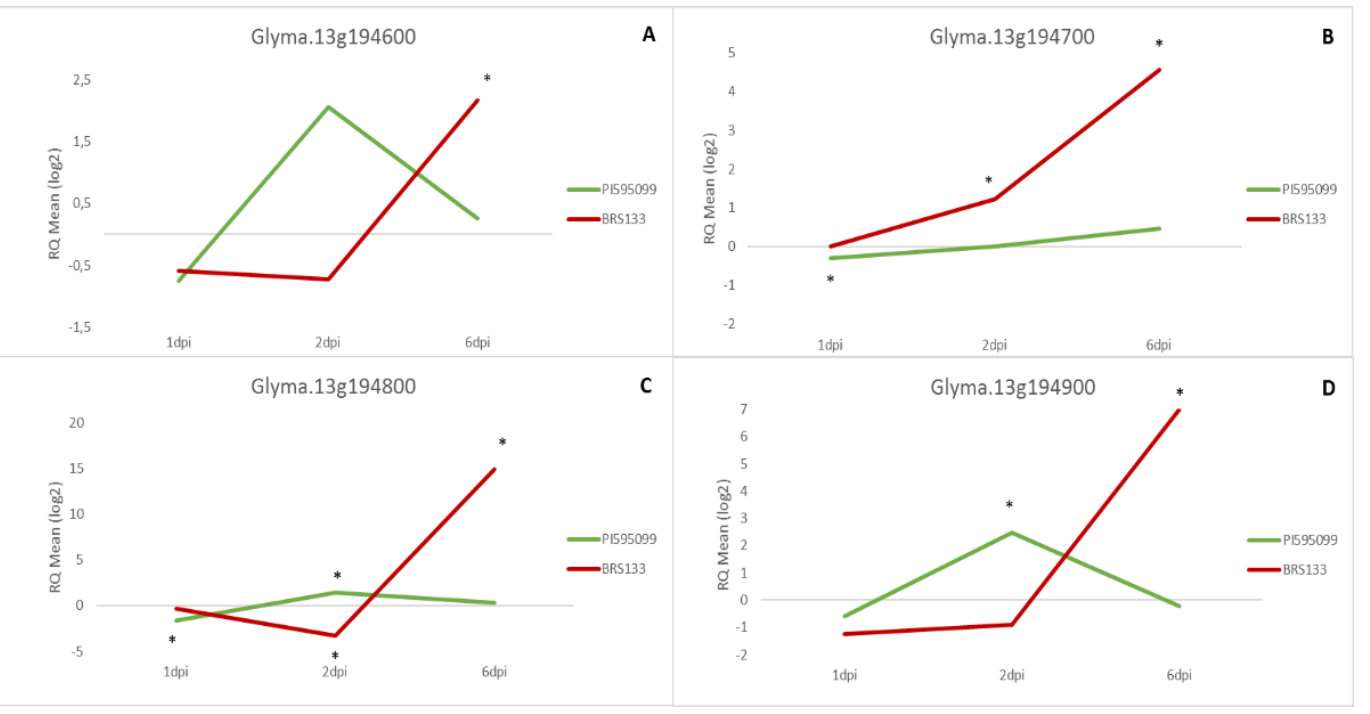

Figure 6. Gene expression profile, gene expression of Glyma.13g194600 (a), gene expression of Glyma.13g194700 (b), the gene with pattern expression differentiated, gene expression of Glyma.13g194800 (c), gene expression of Glyma.13g194900 (d). * Significant expression level at 95\% probability. 


\section{Discussion}

\subsection{M. javanica Reaction in the Soybean Accessions}

The root-knot nematode causing by M. javanica is one of the most important problem for soybean around the world. Therefore, the development of resistance cultivars to this pathogen is essential for the plant breeding programs. To achieve this goal, the identification of both sources of resistance and molecular markers linked to resistance loci are fundamental. In the present study, the characterization of $M$. javanica reaction in a collection of 317 soybean accessions from different origins was performed by an inoculation approach using a fixed initial population of 5,000 eggs. As results, few accessions showed strong resistance to this nematode, among these resistance accessions were present the known resistance sources PI 595099, PI 230977, cv. Bragg, cv.CD 201. It should be noted that in the literature, there are differences in the phenotype approach to access the M. javanica resistance in soybean accessions, mainly based on the number of eggs of J2 infective stage used for inoculation. Other studies related to screening for resistance to $M$. javanica applying higher number of eggs in soybean have been showed similar results for the known resistance sources. For example, in order to search resistance to $M$. javanica, three inoculum density was used $(2,000,5,000$ and 10,000 eggs) and the PI 230977 showed high levels of resistance for all densities tested [7]. Other studies, in order to identify molecular markers related to M. javanica in PI 230977 [10] used 2,000 eggs, while in PI 595099 and CD 201 used 3,000 eggs [12]. In the screening studies for resistance in Brazilian cultivars, it was used 2,000 eggs [27] and 4,000 eggs [28]. Susceptible known accessions used in other studies, as cv. BRS 133 [12,13] and cv. BRSMG Nobreza [26], showed high levels of susceptible in our results. Indeed, seems that even with difference in phenotype approaches and few accessions showing incongruences between genotype and phenotype, all the know sources keep showing resistance to M. javanica, corroborating with the literature. In our phenotype data, we used a higher eggs number for inoculation than the other studies, and only the know sources and few other accessions showed resistance. Therefore, showing that the nematode population used in our study was able to appropriately identify the $M$. javanica resistance.

\subsection{GWAS related to root-know nematode causing by M. javanica and haplotype analysis}

We genotyped a diverse set of 317 accessions with approximately 45K SNPs by GBS. The distribution of the SNPs in the soybean genome was enough to cover all the chromosomes and it was distributed in intergenic and genic regions. Taking account the average size of the blocks was 150 $\mathrm{kbp}$ and the soybean genome size is about 1 GB [29], it would be necessary 6,667 SNPs to represent all the LD blocks. Here, we used for GWAS approximately 30K SNPs, that was enough to represent all the genome. Nowadays, SNPs obtained by GBS have been successfully used for GWAS related to soybean diseases. For example, using 188 accessions genotyped with 46,196 SNPs provided by GBS, it was possible to identified SNPs associated with resistance to $M$. incognita in chromosome 10. A similar approach, using 295 accessions genotyped with 32,836 SNPs by GBS, also identified SNPs in chromosome 14 related to southern stem canker causing by $D$. aspalathi [23].

Even previous genetic mapping studies reporting a locus related to resistance to $M$. javanica in the chromosome 13, as far we know, our study is the first to identified SNPs markers related to $M$. javanica resistance by GWAS, significantly narrowing down the region, being able to identify potential resistance genes in the locus. Indeed, almost all the GWAS previous reported are focused in soybean cyst nematode (SCN) causing by Heterodera glycines, identifying SNPs related to SCN race 1 [30], race 3 [31,32], SCN HG Type 2.5.7 [22,33].

The SNPs identified in the chromosome 13 were in the same LD block and explained around 34\% of the phenotypic variation. These SNPs are located at the same genomic region previous reported 
by previous QTL-mapping studies for root-knot nematode resistance. The first mapping study was performed with $\mathrm{F}_{2}$ population derived from a cross between the M. javanica resistant source (PI 230977) and cv. CNS (susceptible). Through RFLP markers, the marker B212-1, which is physically located around the $29,000,00 \mathrm{bp}$ on chromosome 13 , explained $46 \%$ of phenotypic variation [10]. The B212-1 marker was also identified and explained $62 \%$ of phenotypic variation by other study using a $\mathrm{F}_{2}$ progeny derived from a cross using the resistant cultivar Gazelle [34]. Further genetic mapping studies showed that the resistance in PI 595099 and CD 201 was also identified in the same locus on chromosome 13, and the SSR markers, SOYHSP $176(29,041,580 . .29,041,673)$ and Sat 133 $(24,949,516 . .24,949,765)$, associated with these two sources, respectively [12,35]. Interestingly, using a $F_{2}$ progeny with the PI 200538, resistant to M. arenaria and RFLP markers, it was identified the same RFLP marker (B212-1) as linked to the resistance [11]. In our results, the PI 200538 was classified as moderately resistant and shared the resistant alleles on chromosome 13. Furthermore, the PI 595099 was also described as resistant to M. arenaria [36]. Altogether, our results and the literature, leading the assumption that the locus in chromosome 13 is related to resistance to both M. javanica and $M$. arenaria and is a main source of resistance to root knot nematode in soybean. In addition to the previous sources of resistance to M. javanica described in the literature, our work identified more 20 accession sharing the resistant haplotype, being 10 adapted Brazilian cultivars that can be useful for breeding program. Furthermore, we identified five resistant accessions showing the susceptible haplotype on chromosome 13, which may be due to phenotyping/genotyping errors or potentials new resistance sources to $M$. javanica.

By the analysis of the five peak SNPs, it was observed the redundancy of these SNPs, which means, they bring the same information, corroborating with the LD analyses. It is important to have options of SNPs associated with the same trait for the development of TaqMan and KASP assays to apply in the marker-assisted selection programs. Taking account that in some cases, the peak SNPs identified by GWAS are located in genomic regions which are difficult to design primers and probes, the SNPs identified here were able to correctly discriminate resistant from susceptible accessions. Using only the peak SNP, it is possible to assist the gene introduction at chromosome 13 derivate by new 25 resistant sources of root knot nematode resistance.

In order to provide more information about the distribution of the locus in chromosome 13 related to $M$. javanica, we investigated the presence of the peak SNPs in the entire USDA soybean germplasm. As we expected, the known M. javanica sources as PI 595099, PI 230077 and cv. Bragg, showed the resistance allele, as well as the PI 200538, the M. arenaria resistance source. Interestingly, the screening using our peak SNP linked to M. javanica resistance in the soybean USDA collection identified many accessions, that also have had already described as containing resistance to other nematodes species. In the evaluation of soybean accessions for resistance to multiple nematodes species, the cv. Peking, PI 339868 B, PI 404166, PI 437679, PI 89772, PI 90763, showed resistance to various race of $H$. glycines and Rotylenchulus reniformis, as well as cv. Forrest, that showed resistance to $H$. glycines, R. reniformis and M. incognita [37]. Altogether, all these accessions shared the SNPs related to $M$. javanica on chromosome 13. Another study related to M. incognita screening in American cultivars [38] identified the cv. Bragg, Braxton, Forrest, Haskell, Gordon, Perrin as resistance to $M$. incognita, and similarly all of these cultivars also shared the SNPs on chromosome 13. For the plant breeding programs purposes, this information might be useful to select sources to introgression of multiple resistance for nematodes species.

\subsection{Expression analyses of candidate genes for resistance to $M$. javanica}

The majority of the resistance genes are characterized by the presence of a C-terminal leucinerich repeats (LRRs) and a central nucleotide binding site (NBS) domain [39,40]. Genes for resistance to nematodes have been identified and cloned in different crops, and the majority of them are described as LRR-NBS-type genes; for example, R genes for M. incognita in tomato (Mi-1 and Mi-9 
genes) [41], pepper (CaMi) [42], for Meloidogyne floridensi in Prunus species (Ma) [43], for M. incognita and Heterodera schachtii in Arabidopsis (NILR1) [44], and for M. javanica in cowpea (QRk-vu9.1)[45].

In our results, the SNPs associated with the resistance to $M$. javanica are located in a small region of approximately $13 \mathrm{kbp}$, in which, just the Glyma13g.194700 is present. Fortunately, the Glyma13g.194700 is described as disease resistance protein TIR-NBS-LRR class type (https://www.soybase.org). Surrounding the region, all the genes are described as putative resistance genes. The Glyma13g.194500 is a NB-ARC domain-containing disease resistance protein, while Glyma13g.194600, Glyma13g.194800 and Glyma13g.194900 present structural TIR-NBS-LRR class. The organization of the loci containing resistance genes in plants commonly combine a cluster of genes with same structural organization. In soybean, for example, Ashfield et al. [46] showed that the resistance Rpg1-b locus for Pseudomonas syringae pv. glycinea, is located in a region containing several tightly linked families of NBS-LRR genes on chromosome 13. Interestingly, the Rpg1-b is reported as the Glyma13g.190300, located $371 \mathrm{kbp}$ from the Glyma13g.194500.

Regarding the gene expression levels of the candidate genes mapped in the interval evaluated by RT-qPCR, for the Glyma13g.194500, we were not able to detect any expression levels. Taking account the expression patterns provided by the transcriptome of the soybean root hair cell by Libault et al [47] and the RNA-seq atlas for soybean [48], it was observed that Glyma13g.194500 did not show expression on roots, leading the assumption that probably this gene is not active on roots or is a pseudogene. Studies have showing that $\mathrm{R}$ genes are clustered in plants, however, some of them are not functional (pseudo-genes) and other coffering resistance to members of distinct groups of pathogens or to multiple races of a single pathogen [49,50]. For example, the Mi-1 locus (also known as Mi-1.2) from Solanum lycopersicum confers resistance to M. incognita, M. javanica and M. arenaria, in that locus there are also other two genes, Mi-1.1 and Mi-1.3, however, only Mi-1.2 confers resistance to root-knot nematodes and insects [51,52].

Interestingly, from the other four genes analyzed in our study, three of them (Glyma13g.194600, Glyma13g.194800 and Glyma13g.194900) were firstly induced in the resistant genotype at 2 dpi, and only later in the susceptible one, giving the assumption that the timing of induction might be important factor in the resistance response to $M$. javanica in soybean. As expected, the initial recognition of the pathogen by the resistance genes, followed by signal transduction cascade, might to contribute with the global gene activation towards to the nematode resistance on soybean. On the other hands, Glyma13g.194700 was only significantly induced in the susceptible cv. BRS 133 after 6 dpi. It is possible that the times evaluated in our study may not be enough to capture all profile of the gene expression, such us, few hours after penetration. Indeed, the genes up-regulated in $M$. incognita showed high levels of expression in $12 \mathrm{dpi}$ [53], many hours before the first timeline we have evaluated.

Recently, by the fine-mapping of a locus conferring resistance to Soybean Mosaic Virus (SMV) identified a region of $79 \mathrm{kbp}$ on chromosome 13 [54], and among the genes located in the region, it was identified the Glyma13g.194700, which had high gene expression levels at 8 hpi (hours post inoculation) [55]. Locus conferring both resistance to nematode and virus was already described. For example, the Gpa2 locus is described as R-gene cluster, which contain gene conferring resistance to potato virus $X$, and other gene conferring resistance to potato cyst nematode Globodera pallida [56,57]. So, it is still possible consider Glyma13g.194700 as a potential candidate gene for root knot nematode resistance in soybean, however the expression profile is not expected.

The expression levels of Glyma13g.194800 and Glyma13g.194900, up-regulated in the resistance accession PI 595099 and down-regulated in cv. BRS 133 at 2 dpi, also revels these genes as the potential $\mathrm{R}$ gene for root knot nematodes in this locus in soybean genome. These two genes were strongly expressed in soybean roots in both in transcriptome studies provided by soybase. Recently, these two genes were also identified by fine-mapping approach in the locus related to SMV and Bean 
Common Mosaic Virus (BCMV) resistance in cv. Raiden [58]. And due the differences in the gene sequence, the authors pointed out the Glyma13g.194800 as a strong candidate for resistance to SMV and BCMV.

By sequencing the region in which the 176 SoyHSP-SSR marker was located, Fuganti et al. [24] identified that the SSR marker was located inside of the promotor region of the small heat-shock protein - HSP20 (Glyma.13G176000) on chromosome 13. By RT-qPCR, the authors identified higher expression levels of HSP20 in the PI 595099 in presence of the M. javanica than in cv. BRS. 233. Studies have been showing that heat shock proteins are important to plant resistance. For example, studies using model plant species revealed that R proteins require the co-chaperone protein complex HSP90SGT1-RAR1 to achieve correct folding, maturation, and stabilization[59,60]. Silencing the HSP90 in tomato, increased the number of eggs and galls in tomato plants exposed to M. javanica [61]. As well as, it was demonstrated that the PsoRPM2 gene coding a TIR-NB-LRR-type protein in Tobacco has high expression levels in presence of M. incognita, it was also observed that PsoRPM2 gene interacted with the HSP90 protein [62]. Furthermore, several Hsp20 proteins in soybean were reported as differentially expressed in PI 595099 and cv. BRS 133 in response to M. javanica and may play key roles in the resistance [63].

Altogether, these results showed that LRR-genes are the mainly $\mathrm{R}$ genes related to nematode resistance to several plant species, however, genes coding for heat shocks proteins also play key roles to resistance. Furthermore, the LRR-NBS-type gene cluster located in the chromosome 13 seems to be related to soybean resistance to different pathogens as virus and nematodes. These findings will be useful for selecting multiple resistance in plant breeding programs.

\section{Materials and Methods}

\subsection{Evaluation of M. javanica reaction}

A set of 317 accessions composed of cultivars and PIs (Supplementary Table S), were obtained from the Soybean Germplasm Bank, located at Embrapa Soja in Londrina, PR, Brazil. Six seeds of each accession were pre-germinated in plastic pots of $0.25 \mathrm{~L}$ filled with sterilized sand. Five days after germination, seedlings were transferred individually to plastic tubes of $0.5 \mathrm{~L}$ filled with substrate (sterilized by autoclaving) composed by sand and soil (3:1), in a greenhouse. The plants were kept under 16 hours of daylight and supplemented with 600W high-pressure sodium lamps (Light Systems PL). All samples were used for nematode resistance evaluation. Trifoliate leaves from two young plants from each genotype were collected independently, frozen in liquid nitrogen and stored in a $-80^{\circ} \mathrm{C}$ freezer. The leaf samples were ground to a fine powder and stored until DNA isolation.

Nematode inoculation was performed during the summer. One day before transferring seedlings to plastic tubes, some infected soybean roots from a nematode stock were ground in water to obtain the suspension containing M. javanica eggs. The number of eggs was estimated in a Peters' chamber under microscopy and the concentration of the suspension was adjusted to $1250 \mathrm{eggs} / \mathrm{ml}$. The inoculation was performed by deposition of $4 \mathrm{~mL}$ of the nematode suspension in the same hole used to introduce the seedling. Thirty days after inoculation, all plants were individually removed from the tubes. Excess sand and soil around roots was carefully removed and roots were washed in running water. The severity of the infestation was rated on a scale of 1 to 5 adapted from [64], where $1=<10 \%$ of the root system is infected with small galls; $2=10 \%-25 \%$ of the root system galled, most being small galls; $3=26 \%-50 \%$ of the root system with large galls; $4=51 \%-90 \%$ of the root system with large galls; $5=91 \%-100 \%$ of root system with large galls and necrotic roots. Accessions with a rating between 1 and 2.5 were considered resistant $(\mathrm{R})$, between 2.6 and 3.5 were deemed moderately resistant (MR); and those with a score above 3.6 were rated as susceptible (S). 
The DNA from each sample was extracted using the DNeasy® Plant Mini Kit (Qiagen) according to the manufacturer's instructions. The DNA integrity was checked by electrophoresis on an agarose gel (1\%) followed by quantification on a NanoDrop ${ }^{\circledR}$ ND1000 spectrophotometer (Uniscience) and diluted with water to a concentration of $10 \mathrm{ng} / \mu \mathrm{L}$. GBS libraries were produced using the protocol described by Elshire et al. [15] and modified by Sonah et al [65]. Thus, DNA was digested using ApeKI enzyme followed by ligation of barcoded adapters and pooling of 96 samples per library. These 96plex GBS libraries were sequenced on either Illumina HiSeq2000 (McGill University-Genome Quebec Innovation Centre, Montreal, QC, Canada) or Ion Torrent (Laval Université, Québec, QC, Canada) DNA sequencers. Using a custom-designed pipeline in perl language (Fast-GBS pipeline [66]), short reads $(\leq 100 \mathrm{bp}$ ) were first split into separate fastq files based on the barcode and then trimmed to remove barcode and adapter sequences. The resulting reads were mapped on the G. max reference genome (v.2) and variants were called with SAM tools. Heterozygous genotypes were replaced with missing data and any accessions with $>80 \%$ missing data were removed from the dataset. Finally, imputation of missing genotypic data was performed using fastPHASE 1.3 [67]. For the GWAS, only loci with a minor allele frequency (MAF) $\geq 0.05$ were used. SNP positions throughout the genome and the prediction of the functional impact of these variants was performed using SnpEff [68].

\subsection{Association mapping and Haplotype analysis}

The Genomic Association and Prediction Integrated Tool - GAPIT [69] was used to conduct GWAS using a Compressed Mixed Linear Model (cMLM) that takes into account both population structure and genetic relatedness between lines. The first three Principal Components (PC) from Principal Component Analysis (PCA) were used to capture and evaluate the population structure and produce a P matrix. A VanRaden Kinship matrix (K) was used to capture genetic relatedness. Marker-trait associations were declared significant using FDR-adjusted p-values with the threshold set at 0.0001 . After filtering for a MAF $\geq 0.05$, all SNPs located on chromosome Chr13 were loaded into PLINK and the correlation coefficient $\left(\mathrm{r}^{2}\right)$ was calculated to pairwise linkage disequilibrium (LD). Haplotype blocks were identified and visualized using Haploview [70]. using default Gabriel's rules [71], confidence interval minimal for strong LD, UPPER $=0,98$, LOWER $=0,7-\mathrm{D}^{\prime}>0,8$ and fraction of strong LD $\geq 0,95$. The most widely used method square allele frequency correlation ( $\mathrm{r} 2)$ was used to assessment of LD decay.

In order to validate the SNPs obtained by GWAS. It was used the soybean USDA germplasm collection previously genotyped with Soy50KArray and imputed with the soybean haplotype map (GmHapmap) constructed using WGS data for 1,007 G. Max accessions. This vcf file is available for the public

in (https://figshare.com/projects/Soybean_Haplotype_Map_GmHapMap_A_Universal_Resource_for_ Soybean_Translational_and_Functional_Genomics/56921). As well as the SNPs were validated in our internal vcf file constructed with WGS data from Brazilian cultivars.

\subsection{Expression levels obtained by $R T-q P C R$}

For investigate the transcriptional regulation and polymorphism in the genes located in disequilibrium block, the expression profile of 5 gene models were quantified by RT-qPCR after pathogen infection on 1, 2 and 6 DPI (days post inoculation), using a susceptible (BRS 133) and resistant (PI 595099) genotypes, under inoculated and false inoculate conditions. After 1, 3, and 6 days of inoculation, roots from non-inoculated and inoculated plants were collected, frozen in liquid nitrogen, and stored at $-80^{\circ} \mathrm{C}$. Using Trizol reagent (Life Technologies), total RNA from samples was extracted. First-strand cDNAs were generated using the SuperScript III First-Strand Synthesis SuperMix (Invitrogen). Primers for each of the five candidate gene models were designed by the software Primer3Plus (http://www. bioinformatics.nl/cgi-bin/primer3plus/primer3plus.cgi) and). The cDNA samples were amplified with primers specific to each gene and for the endogenous control ( $\beta$-actin gene), at a final concentration of 0.1-0.25 $\mu \mathrm{M}$, with the 1X SYBR Green Master Mix Kit 
(Applied Biosystems) in a final volume of $12.5 \mu \mathrm{L}$. The $\mathrm{E}=[10-1 /$ slope $]-1$ formula was employed to calculate the reaction efficiency and to adjust the final primer concentration. PCR efficiency determined using standard curves for each primer pair constructed with serial dilutions (1:10, 1:100 and 1:1000) of the cDNA preparation. The reactions were performed in StepOnePlus Real-Time PCR Systems (Applied Biosystems) following the manufacturer's instructions. After initial steps at $50^{\circ} \mathrm{C}$ for $2 \mathrm{~min}$ and at $95^{\circ} \mathrm{C}$ for $10 \mathrm{~min}$, a two-step program of $95^{\circ} \mathrm{C}$ for $15 \mathrm{~s}$ and $62^{\circ} \mathrm{C}$ for $1 \mathrm{~min}$ was run for 40 cycles. The final relative quantification of each gene compared with the control conditions was estimated considering the $\mathrm{RQ}$ obtained in each biological replicate, represented by each independent experiment, with three replicates each. Significant differences were determined based on estimates of the standard deviation (SD) and with REST software version 2.0.7 $(\mathrm{p}<0.05)$.

\section{Conclusions}

The present study reported the identification of a resistance locus related to M. Javanica on chromosome 13 in soybean. This region is surrounding by LRR-NBS genes, composing a LRR-NBS cluster, in which, genes are already described as related to other soybean diseases resistance. As far we know, our GWAS is the first one reporting SNPs markers associated with the resistance to this important nematode. By our analysis on Brazilian cultivars it was observed high correction levels between the peak SNPs and the phenotype of soybean accessions reported in the literature. Surprisingly, several soybean accessions reported as resistance to other important nematodes species, as M. incognita, M. arenaria and H. glycine shared the SNPs on chromosome 13 in our screening in the USDA soybean germplasm collection. Leading us the assumption that these accessions may possess multiple-resistance to nematodes, which are helpful for plant breeding programs. Furthermore, by the characterization gene expression levels of these genes, it was observed that some of them are upregulated in the resistance accession, PI 595099, and down-regulated in the susceptible cultivar, BRS 133, characterizing as strong candidate genes for future functional validation. Finally, the SNPs identified here can be used in the marker-assisted selection for screening for resistance to $\mathrm{M}$. javanica in soybean breeding programs.

Supplementary Materials: Supplementary materials can be found online.

Author Contributions: J.C.A and E.G.C.F - Performed plant sampling, DNA extraction, data analysis and writing manuscript. A.L.L.P and E.G.C.F - DNA extraction, data generation and analysis and manuscript writing. W.P.D. - Plant seedling and phenotyping; F.B. - GBS pipeline support, manuscript review, F.C.M.G. and R.V.A. - conceived and planned the study and review the manuscript. All authors read and approved the final manuscript.

Funding: This research was funded by Coordination for the Improvement of Higher Levels of Education (CAPES) program and the INCT Plant Stress Biotech Grant from MCT of the Brazilian Government and National Council of Technological and Scientific Development (CNPq). The J.C.A. and E.G.C.F were recipient of fellowship from National Council for the Improvement of Higher Education (CAPES).

Acknowledgments: We would like to thanks the financial support of the Coordination for the Improvement of Higher Level for Education program (CAPES), and Embrapa and National Counsel of Technological and Scientific Development (CNPq) for all the support of this study and Dra. Ivani O. N. Lopes for valuable assistance with statistical analyses and Claudemir O. de Lima assistance with root-knot nematode phenotyping.

Conflicts of Interest: The authors declare no conflict of interest.

\section{Abbreviations}

SNP Single Nucleotide Polymorphism

RKN root-knot nematode 


\begin{tabular}{|c|c|}
\hline M. javanica & Meloidogyne javanica \\
\hline PIs & Plant Introduced \\
\hline GBS & genotyping-by-sequencing \\
\hline LD & linkage disequilibrium \\
\hline NBS & Nucleotide Binding Site \\
\hline LRR & Leucine-Rich-Repeat \\
\hline RFLP & Random Fragment Length Polymorphism \\
\hline AFLP & Amplified Fragment Length Polymorphism \\
\hline SCAR & Sequence Characterized Amplified Regions \\
\hline SSR & Single Sequence Repeat \\
\hline Chr & Chromosome \\
\hline QTL & Quantitative Trait Loci \\
\hline GWAS & genome-wide association study \\
\hline $\mathrm{R}$ & Resistant \\
\hline MR & Moderate Resistant \\
\hline$S$ & Susceptible \\
\hline MAF & Minor Alelle Frequence \\
\hline PC & Principal Component \\
\hline MAF & Minor Allele Frequency \\
\hline K & VanRaden Kinship matrix \\
\hline FDR & False discovery rate \\
\hline $\mathrm{P}$ & Populational structure \\
\hline QQplot & Quantile-Quantile Plot \\
\hline $\mathrm{CVs}$ & Cultivars \\
\hline cMLM & Compressed Mixed Linear Model \\
\hline
\end{tabular}

\section{References}

1. USDA World agricultural production. Foreign Agric. Serv. 2019, 1-31.

2. Lima, F.S.O.; Correa, V.R.; Nogueira, S.R.; Santos, P.R.R. Nematodes Affecting Soybean and Sustainable Practices for Their Management. In Soybean - The Basis of Yield, Biomass and Productivity; InTech, 2017; Vol. i, pp. 95-110.

3. Jones, J.T.; Haegeman, A.; Danchin, E.G.J.; Gaur, H.S.; Helder, J.; Jones, M.G.K.; Kikuchi, T.; Manzanilla-López, R.; Palomares-Rius, J.E.; Wesemael, W.M.L.; et al. Top 10 plant-parasitic nematodes in molecular plant pathology. Mol. Plant Pathol. 2013.

4. Silva, J.F.V.; Ferraz, L.C.C.B.; Arias, C.A. Herança da resistência a Meloidogyne javanica em soja. Nematropica 2001.

5. Wrather, A.; Shannon, G.; Balardin, R.; Carregal, L.; Escobar, R.; Gupta, G.K.; Ma, Z.; Morel, W.; Ploper, D.; Tenuta, A. Effect of Diseases on Soybean Yield in the Top Eight Producing Countries in 2006. Plant Heal. Prog. 2010.

6. Ferraz, L.C.C.B. As Meloidoginoses da Soja: Passado, Presente e Futuro. Relações ParasitoHospedeiro nas Meloidoginoses da Soja 2001.

7. Luzzi, B.M.; Boerma, H.R.; Hussey, R.S. Resistance to Three Species of Root-Knot Nematode 
in Soybean1. Crop Sci. 1987, 27, 258-262.

8. Davis, E.L.; Meyers, D.M.; Burton, J.W.; Barker, K.R. Resistance to root-knot, reniform, and soybean cyst nematodes in selected soybean breeding lines. J. Nematol. 1998.

9. Dias, W.P.; Garcia, A.; Silva, J.F.V.; Cameiro, G.E.D.S. Nematóides em soja: identificação e controle. Embrapa Soja. Circ. 76 2010, 1-8.

10. Tamulonis, J.P.; Luzzi, B.M.; Hussey, R.S.; Parrott, W.A.; Boerma, H.R. DNA markers associated with resistance to Javanese root-knot nematode in soybean. Crop Sci. 1997.

11. Tamulonis, J.P.; Luzzi, B.M.; Hussey, R.S.; Parrott, W.A.; Boerma, H.R. DNA marker analysis of loci conferring resistance to peanut root-knot nematode in soybean. Theor. Appl. Genet. 1997, $95,664-670$.

12. Silva, J.F. V; Ferraz, L.C.B.C.; Arias, C.A.A.; Abdelnoor, R. V Identificacao de Marcadores Moleculares de Microssatelites Associados a Resistencia de Genotipos de Soja a Meloidogyne javanica. Nematol. Bras. 2001, 25, 79-83.

13. Fuganti, R.; Fuganti, R.; Beneventi, M.A.; Beneventi, M.A.; Alberto, C.; Alberto, C.; Arias, A.; Arias, A.; Marin, S.R.R.; Marin, S.R.R.; et al. Identificação de Marcadores Moleculares de Microssatélites para Seleção de Genótipos de Soja Resistentes a Meloidogyne javanica. Genetics 2004, 28, 125-130.

14. Korte, A.; Farlow, A. The advantages and limitations of trait analysis with GWAS: A review. Plant Methods 2013, 9, 1.

15. Elshire, R.J.; Glaubitz, J.C.; Sun, Q.; Poland, J.A.; Kawamoto, K.; Buckler, E.S.; Mitchell, S.E. A Robust, Simple Genotyping-by-Sequencing ( GBS ) Approach for High Diversity Species. 2011, $6,1-10$.

16. Song, Q.; Hyten, D.L.; Jia, G.; Quigley, C. V; Fickus, E.W.; Nelson, R.L.; Cregan, P.B. Fingerprinting Soybean Germplasm and Its Utility in Genomic Research. G3 (Bethesda). 2015, 5, 1999-2006.

17. dos Santos, J.V.M.; Valliyodan, B.; Joshi, T.; Khan, S.M.; Liu, Y.; Wang, J.; Vuong, T.D.; de Oliveira, M.F.; Marcelino-Guimarães, F.C.; Xu, D.; et al. Evaluation of genetic variation among Brazilian soybean cultivars through genome resequencing. BMC Genomics 2016, 17, 1-18.

18. Bastien, M.; Sonah, H.; Belzile, F. Genome wide association mapping of sclerotinia sclerotiorum resistance in soybean with a genotyping-by-sequencing approach. Plant Genome 2014, 7, 1-13.

19. Iquira, E.; Humira, S.; François, B. Association mapping of QTLs for sclerotinia stem rot resistance in a collection of soybean plant introductions using a genotyping by sequencing ( GBS ) approach. BMC Plant Biol. 2015, 1-12.

20. Rincker, K.; Lipka, A.E.; Diers, B.W. Genome-wide association study of brown stem rot resistance in soybean across multiple populations. Plant Genome 2016, 9, 1-11.

21. Passianotto, A.L. de L.; Sonah, H.; Dias, W.P.; Marcelino-Guimarães, F.C.; Belzile, F.; Abdelnoor, R. V Genome-wide association study for resistance to the southern root-knot nematode (Meloidogyne incognita) in soybean. Mol. Breed. 2017, 37, 148.

22. Zhao, X.; Teng, W.; Li, Y.; Liu, D.; Cao, G.; Li, D.; Qiu, L.; Zheng, H.; Han, Y.; Li, W. Loci and candidate genes conferring resistance to soybean cyst nematode HG type 2.5.7. BMC Genomics 2017, 18, 1-10.

23. Maldonado dos Santos, J.V.; Ferreira, E.G.C.; Passianotto, A.L. de L.; Brumer, B.B.; Santos, A.B. 
Dos; Soares, R.M.; Torkamaneh, D.; Arias, C.A.A.; Belzile, F.; Abdelnoor, R.V.; et al. Association mapping of a locus that confers southern stem canker resistance in soybean and SNP marker development. BMC Genomics 2019, 20, 798.

24. Fuganti, R.; Machado, M. de F.P. da S.; Lopes, V.S.; Silva, J.F.V.; Arias, C.A.A.; Marin, S.R.R.; Binneck, E.; Abdelnoor, R.V.; Marcelino, F.C.; Nepomuceno, A.L. Size of $<$ math $><$ msub $>$ $<$ mtext $>$ AT $<$ /mtext $><$ mrow $><$ mrow $><$ mo $>(</$ mo $><$ mi $>$ n $</$ mi $><$ mo $>)</$ mo $><$ mrow $>$ $</$ mrow $></$ msub $><$ /math $>$ Insertions in Promoter Region Modulates Gmhsp17.6-L mRNA Transcript Levels. J. Biomed. Biotechnol. 2010, 2010, 1-9.

25. de Sá, M.E.L.; Lopes, M.J.C.; de Araújo Campos, M.; Paiva, L.V.; dos Santos, R.M.A.; Beneventi, M.A.; Firmino, A.A.P.; de Sá, M.F.G. Transcriptome analysis of resistant soybean roots infected by Meloidogyne Javanica. Genet. Mol. Biol. 2012, 35, 272-282.

26. Beneventi, M.A.; Bonfim, O.; Eugênia, M.; Sá, L. De; Augusto, A.; Firmino, P.; Maria, R.; Amorim, S. De; Valéria, É.; Albuquerque, S.; et al. Transcription profile of soybean-root-knot nematode interaction reveals a key role of phythormones in the resistance reaction. BMC Genomics 2013, 14, 322.

27. Teixeira, R.A.; Barbosa, K.A.G.; Rocha, M.R. da Reaction of soybean cultivars to the root-knot nematode Meloidogyne javanica. Científica 2017, 45, 145.

28. Bruinsma, J.S. da S.; Antoniolli, Z.I. Resistance of Meloidogyne javanica in soybean genotypes. Nematoda 2015, 2, e032015.

29. Schmutz, J.; Cannon, S.B.; Schlueter, J.; Ma, J.; Mitros, T.; Nelson, W.; Hyten, D.L.; Song, Q.; Thelen, J.J.; Cheng, J.; et al. Genome sequence of the palaeopolyploid soybean. Nature 2010.

30. Zhang, H.; Song, Q.; Griffin, J.D.; Song, B.H. Genetic architecture of wild soybean (Glycine soja) response to soybean cyst nematode (Heterodera glycines). Mol. Genet. Genomics 2017, 292, 1257-1265.

31. Tran, D.T.; Steketee, C.J.; Boehm, J.D.; Noe, J.; Li, Z. Genome-Wide Association Analysis Pinpoints Additional Major Genomic Regions Conferring Resistance to Soybean Cyst Nematode (Heterodera glycines Ichinohe). Front. Plant Sci. 2019, 10, 1-13.

32. Vuong, T.D.; Sonah, H.; Meinhardt, C.G.; Deshmukh, R.; Kadam, S.; Nelson, R.L.; Shannon, J.G.; Nguyen, H.T. Genetic architecture of cyst nematode resistance revealed by genome-wide association study in soybean. BMC Genomics 2015, 16, 1-13.

33. Zhang, H.; Li, C.; Davis, E.L.; Wang, J.; Griffin, J.D.; Kofsky, J.; Song, B.-H. Genome-Wide Association Study of Resistance to Soybean Cyst Nematode (Heterodera glycines) HG Type 2.5.7 in Wild Soybean (Glycine soja). Front. Plant Sci. 2016, 7, 1-11.

34. Mienie, C.M.S.; Fourie, H.; Smit, M.A.; Van Staden, J.; Botha, F.C. Identification of AFLP markers in soybean linked to resistance to Meloidogyne javanica and conversion to Sequence Characterized Amplified Regions (SCARs). Plant Growth Regul. 2002, 37, 157-166.

35. Fuganti, R.; Fuganti, R.; Beneventi, M.A.; Beneventi, M.A.; Alberto, C.; Alberto, C.; Arias, A.; Arias, A.; Marin, S.R.R.; Marin, S.R.R.; et al. Identificação de Marcadores Moleculares de Microssatélites para Seleção de Genótipos de Soja Resistentes a Meloidogyne javanica. Nematol. Bras. 2004, 28, 125-130.

36. Luzzi, B.M.; Boerma, H.R.; Hussey, R.S.; Wood, E.D. Registration of Javanese Root-Knot Nematode Resistant Soybean Germplasm Line G93-9223. Crop Sci. 1997, 37, 1035-1036.

37. Klepadlo, M.; Meinhardt, C.G.; Vuong, T.D.; Patil, G.; Bachleda, N.; Ye, H.; Robbins, R.T.; Li, 
Z.; Shannon, J.G.; Chen, P.; et al. Evaluation of soybean germplasm for resistance to multiple nematode species: Heterodera glycines, Meloidogyne incognita, and Rotylenchulus reniformis. Crop Sci. 2018, 58, 2511-2522.

38. Ha, B.; Bennett, J.B.; Hussey, R.S.; Finnerty, S.L.; Boerma, H.R. Pedigree Analysis of a Major QTL Conditioning Soybean Resistance to Southern Root-Knot Nematode. Crop Sci. 2004, 44, 758-763.

39. Pan, Q.; Wendel, J.; Fluhr, R. Divergent evolution of plant NBS-LRR resistance gene homologues in dicot and cereal genomes. J. Mol. Evol. 2000.

40. Hammond-Kosack, K.E.; Parker, J.E. Deciphering plant-pathogen communication: Fresh perspectives for molecular resistance breeding. Curr. Opin. Biotechnol. 2003.

41. Jablonska, B.; Ammiraju, J.S.S.; Bhattarai, K.K.; Mantelin, S.; De Ilarduya, O.M.; Roberts, P.A.; Kaloshian, I. The Mi-9 gene from Solanum arcanum conferring heat-stable resistance to rootknot nematodes is a homolog of Mi-1. Plant Physiol. 2007, 143, 1044-1054.

42. Chen, R.; Li, H.; Zhang, L.; Zhang, J.; Xiao, J.; Ye, Z. CaMi, a root-knot nematode resistance gene from hot pepper (Capsium annuum L.) confers nematode resistance in tomato. Plant Cell Rep. 2007, 26, 895-905.

43. Claverie, M.; Dirlewanger, E.; Bosselut, N.; van Ghelder, C.; Voisin, R.; Kleinhentz, M.; Lafargue, B.; Abad, P.; Rosso, M.N.; Chalhoub, B.; et al. The ma gene for complete-spectrum resistance to meloidogyne species in prunus is a TNL with a huge repeated c-terminal postLRR region. Plant Physiol. 2011, 156, 779-792.

44. Mendy, B.; Wang'ombe, M.W.; Radakovic, Z.S.; Holbein, J.; Ilyas, M.; Chopra, D.; Holton, N.; Zipfel, C.; Grundler, F.M.W.; Siddique, S. Arabidopsis leucine-rich repeat receptor-like kinase NILR1 is required for induction of innate immunity to parasitic nematodes. PLoS Pathog. 2017, 13, 1-22.

45. Santos, J.R.P.; Ndeve, A.D.; Huynh, B.L.; Matthews, W.C.; Roberts, P.A. QTL mapping and transcriptome analysis of cowpea reveals candidate genes for root-knot nematode resistance. PLoS One 2018, 13, 1-22.

46. Ashfield, T.; Bocian, A.; Held, D.; Henk, A.D.; Marek, L.F.; Danesh, D.; Peñuela, S.; Meksem, K.; Lightfoot, D.A.; Young, N.D.; et al. Genetic and physical localization of the soybean Rpg1$\mathrm{b}$ disease resistance gene reveals a complex locus containing several tightly linked families of NBS-LRR genes. Mol. Plant-Microbe Interact. 2003, 16, 817-826.

47. Libault, M.; Farmer, A.; Brechenmacher, L.; Drnevich, J.; Langley, R.J.; Bilgin, D.D.; Radwan, O.; Neece, D.J.; Clough, S.J.; May, G.D.; et al. Complete transcriptome of the soybean root hair cell, a single-cell model, and its alteration in response to Bradyrhizobium japonicum infection. Plant Physiol. 2010.

48. Severin, A.J.; Woody, J.L.; Bolon, Y.T.; Joseph, B.; Diers, B.W.; Farmer, A.D.; Muehlbauer, G.J.; Nelson, R.T.; Grant, D.; Specht, J.E.; et al. RNA-Seq Atlas of Glycine max: A guide to the soybean transcriptome. BMC Plant Biol. 2010.

49. Von Der Weid, I.; Paiva, E.; Nóbrega, A.; Dirk Van Elsas, J.; Seldin, L. Diversity of Paenibacillus polymyxa strains isolated from the rhizosphere of maize planted in Cerrado soil. Res. Microbiol. 2000, 151, 369-381.

50. Peñuela, S.; Danesh, D.; Young, N.D. Targeted isolation, sequence analysis, and physical mapping of nonTIR NBS-LRR genes in soybean. Theor. Appl. Genet. 2002. 
51. Milligan, S.B.; Bodeau, J.; Yaghoobi, J.; Kaloshian, I.; Zabel, P.; Williamson, V.M. The root knot nematode resistance gene $\mathrm{Mi}$ from tomato is a member of the leucine zipper, nucleotide binding, leucine-rich repeat family of plant genes. Plant Cell 1998.

52. Nombela, G.; Williamson, V.M.; Muñiz, M. The root-knot nematode resistance gene Mi-1.2 of tomato is responsible for resistance against the whitefly Bemisia tabaci. Mol. Plant-Microbe Interact. 2003.

53. Pham, A.T.; McNally, K.; Abdel-Haleem, H.; Roger Boerma, H.; Li, Z. Fine mapping and identification of candidate genes controlling the resistance to southern root-knot nematode in PI 96354. Theor. Appl. Genet. 2013, 126.

54. Karthikeyan, A.; Li, K.; Li, C.; Yin, J.; Li, N.; Yang, Y.; Song, Y.; Ren, R.; Zhi, H.; Gai, J. Finemapping and identifying candidate genes conferring resistance to Soybean mosaic virus strain SC20 in soybean. Theor. Appl. Genet. 2018, 131, 461-476.

55. ALMEIDA, Á.M.R.; ALMEIDA, L.A.; KIIHL, R.A.S. Seleção de genótipos de soja resistentes a duas estirpes de Soybean mosaic virus. Fitopatol. Bras. 2001, 26, 99-99.

56. Van Der Vossen, E.A.G.; Van Der Voort, J.N.A.M.R.; Kanyuka, K.; Bendahmane, A.; Sandbrink, H.; Baulcombe, D.C.; Bakker, J.; Stiekema, W.J.; Klein-Lankhorst, R.M. Homologues of a single resistance-gene cluster in potato confer resistance to distinct pathogens: A virus and a nematode. Plant J. 2000.

57. Bakker, E.; Butterbach, P.; Rouppe Van Der Voort, J.; Van Der Vossen, E.; Van Vliet, J.; Bakker, J.; Goverse, A. Genetic and physical mapping of homologues of the virus resistance gene Rx1 and the cyst nematode resistance gene Gpa2 in potato. Theor. Appl. Genet. 2003, 106, 1524-1531.

58. Wu, M.; Liu, Y.-N.; Zhang, C.; Liu, X.-T.; Liu, C.-C.; Guo, R.; Niu, K.-X.; Zhu, A.-Q.; Yang, J.Y.; Chen, J.-Q.; et al. Molecular mapping of the gene(s) conferring resistance to Soybean mosaic virus and Bean common mosaic virus in the soybean cultivar Raiden. Theor. Appl. Genet. 2019.

59. Huang, S.; Monaghan, J.; Zhong, X.; Lin, L.; Sun, T.; Dong, O.X.; Li, X. HSP90s are required for NLR immune receptor accumulation in Arabidopsis. Plant J. 2014.

60. Van Ooijen, G.; Lukasik, E.; Van Den Burg, H.A.; Vossen, J.H.; Cornelissen, B.J.C.; Takken, F.L.W. The small heat shock protein 20 RSI2 interacts with and is required for stability and function of tomato resistance protein I-2. Plant J. 2010.

61. Bhattarai, K.K.; Li, Q.; Liu, Y.; Dinesh-Kumar, S.P.; Kaloshian, I. The Mi-1-mediated pest resistance requires Hsp90 and Sgt1. Plant Physiol. 2007.

62. Zhu, X.; Xiao, K.; Cui, H.; Hu, J. Overexpression of the Prunus sogdiana NBS-LRR subgroup gene PsoRPM2 promotes resistance to the root-knot nematode Meloidogyne incognita in tobacco. Front. Microbiol. 2017, 8, 1-13.

63. Lopes-Caitar, V.S.; de Carvalho, M.C.C.G.; Darben, L.M.; Kuwahara, M.K.; Nepomuceno, A.L.; Dias, W.P.; Abdelnoor, R. V.; Marcelino-Guimarães, F.C. Genome-wide analysis of the Hsp20 gene family in soybean: Comprehensive sequence, genomic organization and expression profile analysis under abiotic and biotic stresses. BMC Genomics 2013, 14.

64. Dall'Agnol, A.; Antônio, H. Reação de genótipos de soja aos nematóides formadores de galhas Meloidogyne incognita e M. javanica. Soc. Bras. Nematol. 1982, 51-77.

65. Sonah, H.; Bastien, M.; Iquira, E.; Tardivel, A.; Légaré, G.; Boyle, B.; Normandeau, É.; Laroche, J.; Larose, S.; Jean, M.; et al. An Improved Genotyping by Sequencing (GBS) Approach 
Offering Increased Versatility and Efficiency of SNP Discovery and Genotyping. PLoS One 2013, 8, 1-9.

66. Torkamaneh, D.; Laroche, J.; Bastien, M.; Abed, A.; Belzile, F. Fast-GBS: A new pipeline for the efficient and highly accurate calling of SNPs from genotyping-by-sequencing data. BMC Bioinformatics 2017, 18, 1-7.

67. Scheet, P.; Stephens, M. A fast and flexible statistical model for large-scale population genotype data: Applications to inferring missing genotypes and haplotypic phase. Am. J. Hum. Genet. 2006.

68. Cingolani, P.; Platts, A.; Wang, L.L.; Coon, M.; Nguyen, T.; Wang, L.; Land, S.J.; Lu, X.; Ruden, D.M. A program for annotating and predicting the effects of single nucleotide polymorphisms, SnpEff. Fly (Austin). 2012.

69. Lipka, A.E.; Tian, F.; Wang, Q.; Peiffer, J.; Li, M.; Bradbury, P.J.; Gore, M.A.; Buckler, E.S.; Zhang, Z. GAPIT: Genome association and prediction integrated tool. Bioinformatics 2012, 28 , 2397-2399.

70. Barrett, J.C.; Fry, B.; Maller, J.; Daly, M.J. Haploview: Analysis and visualization of LD and haplotype maps. Bioinformatics 2005.

71. Gabriel, S.B.; Schaffner, S.F.; Nguyen, H.; Moore, J.M.; Roy, J.; Blumenstiel, B.; Higgins, J.; DeFelice, M.; Lochner, A.; Faggart, M.; et al. The structure of haplotype blocks in the human genome. Science (80-. ). 2002. 
(C) 2019 by the authors. Submitted for possible open access publication under the terms and conditions of the Creative Commons Attribution (CC BY) license (http://creativecommons.org/licenses/by/4.0/). 